Rasim M. Alguliyev', Farhad F. Yusifov ${ }^{2}$

DOI: 10.25045/jpis.v06.i2.05

${ }^{1,2}$ Institute of Information Technology, ANAS, Baku, Azerbaijan

${ }^{1}$ secretary@iit.ab.az, ${ }^{2}$ farhadyusifov@gmail.com

\title{
FROM REPRESENTATIVE DEMOCRACY TO DIRECT DEMOCRACY: CONCEPTUAL VIEWS ON SOCIETY MANAGEMENT
}

The paper investigates views on the transformation of public administration and the formation of electronic democracy or e-democracy. The transition process from a representative democracy to a direct democracy is analysed, and meritocracy is viewed as a public administration mechanism. Conceptual approaches to society management and perspectives on the development of the mechanisms of e-democracy are discussed.

Keywords: public administration, electronic government, electronic democracy, direct democracy, meritocracy.

\section{Introduction}

The transformation of political institutions and public administration in accordance with the requirements of the information age and globalisation are apparent. In the context of deepening globalisation processes, national governments aspire to maintain the establishment of international cooperation and the links between governments and citizens at the required level through changes in public administration.

McLuhan has first suggested the concept of "communication age" in 1962 [1], and the amount of research on the information age and information society have increased recently. The work of researchers such as Young (1958), Bell (1972-1973), Toffler (1980), Becker (19812007), Masuda (1981-1990), Robertson (1990), Habermas (1991), Rheingold (1993), Freeman and Seit (1997), Castels (1996-2002), Weiner and Brown (1997), Drucker (1999), Hedrick (2002), Webster (2002), Vimmer (2003), Schedler (2002-2004) and Briggs and Berg (2004),includes research on information revolutions, the information age, the communication age, information society, teledemocracy, direct democracy, public administration, society management and meritocracy.

The development of information communication technologies (ICT) affects social, economic and political life. Specifically, developments of ICT, electronic government (egovernment) and the building of electronic democracy (e-democracy) mechanisms have significantly modified public administration and political processes. Currently, advanced technologies and the requirements imposed on state government services are transforming the functions of e-government. For the formation of efficient public administration mechanisms, the development of a new e-government concepts targeting direct democracy is essential. Civil rights and widespread participation in social processes and decision-making facilitate efficiency and democracy in public administration.

The analysis of the published scientific literature on e-government in 2005-2010 in developing countries reveals anincrease of interest in several research areas, including research methodologies and paradigms, higher quality scientific research and the development of a conceptual basis for e-government [2]. The main research topics include the factors affecting the development of e-government, the impact of e-government on governmental entities and citizens and the link between ICT infrastructure and e-government [3]

The informatisation process is part of the trajectories of all countries. As a result of the rapid development of ICT and the effects of information revolutions, the considerable digital divide among governments in different regions of the world will be observed in near future. The relationship between information revolutions and e-government development perspectives are investigated in this article. The views on reforms performed in public administration and the process of building an e-government are discussed. The conceptual approaches to the formation 
of e-democracy, meritocracy and the society are commented upon. The factors affecting the transition to an information society and the development of e-democracy mechanisms are described.

\section{The impact of information revolutions on the formation of e-government}

Because of globalisation processes, the role of information in society is increasing. If we consider the evolution of society from the perspective of the broadening role of information in human life, several information revolutions are apparent [4,5]. The establishment of new communication tools and the emergence of new technologies in the sphere of information processing have led to the reformation of the relations between the government and citizens.

Through the process of computerisation, informatisation relieves workers from everyday routine tasks by providing secure access to information resources, leading to the opportunity for high-level automatisation of information processing in the government, production and social spheres. Economic development and the informatisation of social relations stimulate reforms in government administration in accordance with the demands of the information age. The formation of e-government leads to transformation in all spheres of society, which creates qualitatively new information and communication environment for the realisation of direct democracy [6].In comparison with an industrial society, more information is produced and consumed in an information society. This, in turn, causes the share of intellectual labour to expand, requiring people's creative skills and increasing the need for knowledge.

All countries implement the informatisation process differently depending on their level of development. There are national informatisation programs pursued by the governments that take into account local characteristics. The rapid development of information technologies and the impact of information revolutions will lead to digital divide between regions of the world in the near future. The incorrect selection of informatisation strategy can affect all spheres of activity. According to another approach, information revolutions are one means of transforming financialeconomic relations globally. In the near future, information revolutions could substantively affect public administration mechanisms and lead to the formation of new political structures.

Traditional mechanisms for managing society (e.g., taxes, regulation, licensing, etc.) are considered increasingly inefficient. The impact of information revolutions on public administration necessitates the establishment of new mechanisms or international management structures. Specific mechanisms include a well-developed infrastructure to enable the rapid adaptation to any changes in public administration and a legislative framework for the protection of intellectual property rights. Yet, the pace of technological revolutions will trigger the deepening of inequality and digital divide among nations.

\section{The transformation of public administration and electronic democracy}

Communication or information revolutions alter management concepts and political technologies. These modifications necessitate the formation of e-government as a technological solution to several management issues, and the projection of relations between the state and citizen to the virtual space. In this regard, the attempts to increase the activities of governments and to create an electronic space to achieve political power are understandable.

Rahman et al. [7] identify the potential factors of applying e-government in their literature review on e-government, classifying those factors into four categories: institutional, resources, access opportunities and legal aspects. Chen et al. [8] suggest tools and strategies for the application of e-government. Ozkan et al. [9] show that an increasing number of countries have adopted the e-government strategy after considering the advantages such as the strengthening of activities in the sphere of public administration and increased efficiency. Sharif et al. [9] state that e-government formation depends on technological issues and the complicating human, social, cultural and economic factors. Bwalya et al. [11] comment on problems encountered in 
the sphere of e-government formationin developing countries. Alshehri et al. [12] have analysed recent research regarding the stages of e-government and existing problems and advantages in e-government. The research of Siskos et al. [13] recommends a system consisting of eight criteria to assesse-government. The assessment of e-government is based on four parameters: infrastructure, investment, electronic processes and users' attitude.

The formation of electronic technologies and their use in public administration changes the character of administration. Authority in an information society derives from new structure and administration principles, with approaches focussed on electronic administration. The notion of electronic administration is characterised by the establishment of horizontal rather than vertical administration due to fewer normative restrictions on administrative activity and organisations. Authority differs from traditional administration in which state authority and administration is postulated as the highest level of hierarchy in decision making. This form of new management is distinguished from the hierarchy model of administration, and it is considered to be more efficient in satisfying the public demand.

The differences between traditional government and the new administration concept c0an be identified based on several criteria. Unlike the traditional government, the main features of the new administration are consent, bargaining and agreement. If traditional government preferred legislation and regulations, the new administration principles and the source of governmental authority in a networked society mainly include commissions, forums and democratically organised groups. If previously administrative information was centralised and closed, now information is shared, open, transparent and discussed in network forums.

The research shows that the views of researchers on the realisation of reforms in public administration and the concept of e-government formation differ. Some researchers suggest that the initiatives completely differ from previous approaches or that e-government formation increases the efficiency of governmental activities and forms an implicitly new public administration model. Other researchers have a more cautious stance and consider e-government as a new tool for solving the existing problems. In this regard, three elements of e-government have been identified $[14,15]$ :

1. Electronic democracy and participation -the formation of public opinion and decision making with the help of electronic tools (e-voting, citizen networks, etc.)

2. Electronic production network -a tool for cooperation among public institutions and civil society institutions.

3. Electronic public services -the provision of services to users, citizens or the business sector via national, regional or local portals.

The first element is related to a political system in general, and the other two elements can be seen as the continuation of the reforms achieved at any level [14]. Efficiency in administration can be achieved through the active participation of citizens and civil societies in the process of political-administrative decision making. According to some researchers, the transition from the term e-government to e-democracy is necessary [16-19]. The framework of this process is built through an increase in the trust of government agencies and a corresponding trust in citizens. The development of democratic institutions and the use of ICT and information infrastructure for the purpose of broadening the participation of citizens in public and political processes reflect the essence of e-democracy [17,19,20]. In the broad sense, e-democracy can be defined as the engagement of citizens and organisations in political processes by considering their thoughts and opinions. Reviewing the evolution of the notion of e-government reveals several important phases of its development. First, the notion of "teledemocracy" emerged with the creation of cable television at the end of the 1960s and the beginning of the 1970s [21, 22]. According to some researchers, teledemocracy can be viewed as the precursor of e-democracy. Teledemocracy is expressed as enabling the participation of citizens in any political debate by using the television andtelephone at the same time. The viewer ofany political event on 
television can participate in that event by using the telephone. The main purpose of teledemocracy was the participation of citizens in political processes and the realisation of structural reforms based on the existing technical feasibilities of communication tools $[21,22]$. However, in the 1980s, the experiments conducted using the television and telephone neither determined the establishment of new form of democracy, nor the efficiency of the participation of citizens in political processes.

Teledemocracy constituted the framework for a future "electron republic" [23, 24], resting on the theoretical foundations of reforms in the sphere of public administration developed by Habermas at the end of the 1980s [25]. Based on Habermas' theories, researchers have studied the mutual relationship between new technologies, the formation of the structure of civil society and the impact of information infrastructure and the Internet on democracy. The research conducted on cyberspace formation led to the emergence of the notion of "cyberdemocracy", which started to be considered as a main concept of the transformation to e-democracy [18, 26, 27]. In this period, the concept of the "virtual society" suggested by Rheingold was justified by the fact that computer networks would become a tool to stimulate the formation of necessary social capital for the strengthening of democratic values [26].

The first stages of the formation of e-democracy confined citizens' access to information to that which was publicly important, and included the opportunity to vote on government decisions. In subsequent evolution processes, the opportunities of both parties were widened and an opportunity was created to select the extent of participation in processes of citizens [27-30]. This was considered to be an opportunity for citizens to express their opinion freely at any level of decision making and to increase transparency considerably.

In the literature, different concepts of e-government and e-democracy exist. ICT experts believe that e-democracy must be viewed as an integral part of e-government. Experts on the social sphere have the opposite perspective, which is that e-government must be viewed as an integral part of e-democracy. It can be concluded that e-government is created by the initiative of the upper level of the hierarchy for the purpose of serving government interests. E-democracy can emerge from the lower level of the hierarchy as it reflects the interests of citizens. If the state responds to current trends, e-government can be a strong and effective administration mechanism that solves several social problems and initiates a direct dialogue between the citizen in a democratic society and the government, that is, a transition from a representative democracy to direct democracy.

\section{From direct democracy to meritocracy}

The transition from an industrial society to an information society is characterised by the development of information technologies, the individualisation of collective values and the modification of the role of government to the desired form. This leads to the transformation of political institutions of democracy. In several studies, the Internet is considered to bean important tool for strengthening the direct democracy. The characteristics of political socialisation and the cultural level of the population are considered as serious impediments for the Internet to become a tool of direct democracy in the near term.

Cyberspace democracy (e.g., the discussion of political problems in social networks) is not yet a real-world democracy. The discussion of political issues in the virtual environment does not lead to activity in real life $[18,27,29,30]$. Asceptical approach to direct democracy in the mass media does not lead to an increase in attention to forms of democracy through the use of the Internet. In developed countries, the use of the Internet as a main mechanism of e-democracy broadens access to opportunities and the participation of electors and mass media and it increases the effectiveness of the feedback that citizens provide to government agencies.

Based on an egalitarian concept of democracy, it is assumed that the solution to all important government issues lies in the voting process that reflects the opinion of the majority. 
In this case, everyone has an equal right to vote and no difference exists in the votes of voters. This mechanism seems simple at first sight but cannot be accepted as a factor in real public administration as such. A need for sufficiently varied solutions for different types of problems in the government causes the manipulation of problems in administrative decision making, psychological impact on public opinion and distorted results. This is a form of quantitative democracy, not direct democracy.

Figuratively speaking, the principal "currency" of democracy is information and communication. In the presence of those currencies, the citizens are organised, self-governed and an e-citizen is formed. Social networks and blogs play a prominent role in the formation of civil societies. As civil society or a horizontal relations system is formed, self-governance opportunities are established, meaning that some functions of the state are handed over to public institutions and local self-governance bodies. Other functions (production, sales, etc.) are conducted by the business sector.

In 1958, Young'sbook The Rise of the Meritocracy: 1870-2033describeda futuristic society in which the society was managed according to the intelligence quotient (IQ) of people [31]. In 1973, in his book The Coming of Post-Industrial Society, Bell noted that in the near future the meritocracy would eradicate the bureaucracy and the social structure of the society would be altered [32].

If in the 1990's a person's IQ exceeded 125, they were assigned to ruling class of meritocrats [31]. Formerly, people of high intelligence were encountered at different levels of the social hierarchy, and usually they gained a particular status of leadership within that social class. Now, a solid intellectual elite has been formed. According to this approach, society should be managed by people with the intellect and skills deserving of the highest level of the social hierarchy $[33,34]$. Yet, people's living standards and rights must not vary depending on their level of education and intellect. Although different approaches exist with in meritocracy ideology, the transition to an information society and the rapid development of innovation technologies mean that meritocracy remains a mechanism for managing society preserving humanistic values, and forming a democratic society.

\section{E-democracy mechanisms}

At present, the states carry out initiatives, projects, and strategies at regional, national and local levels to transition to information society and develope-democracy mechanisms. For example, "The National Strategy on Development of the Information Society in the Republic of Azerbaijan for 2014-2020" includes the goals of effective regulation under the conditions of an information society, the expansion of e-government and the increase of effectiveness of public administration with application of ICT, the development of democratic principles and the achievement of high-quality electronic services [35].

The transition to an information society is not confined to the reforms implemented in public administration and requires the development of democratic principles, e-democracy mechanisms and the construction of those based on citizens' interests.

The following are suggested as development directions fore-democracy principles:

- The strengthening of relations between citizens and government bodies and the increase of effectiveness;

- The strengthening of horizontal links between citizens and the provision of openness;

- The formation of a communication and information culture between the government bodies and other socio-political entities;

- The reduction of administrative obstacles and corruption and transparency in establishing the relations between government bodies and civil societies;

- The development of electronic voting mechanisms; 
- The mechanisms for citizens' participation in discussion of socio-political issues and socially important problems in online fora;

- The mechanisms for the formation of online society;

- The presence of public administration mechanisms at the level of local executive authorities;

- The formation of citizen control mechanisms on the activity of government bodies;

- The provision of functional activity of electronic document turnover and the considerable reduction of the impact of human factors;

- The support for establishment of social relations of institutions and citizens at all levels of socio-political activity.

Effective administration and e-democracy can be realised through the participation of citizens and civil societies in the socio-political decision-making process. E-democracy promotes more effective relations among the citizens, between the citizens and government structures and between civil society and the business sector. Different approaches to e-democracy exist and those are subject to criticism. The contradictions between the e-government concept which is essential for achieving reforms in the spheres of public administration and e-democracy have been debated in the recent literature.

\section{Conclusion}

Different considerations concerning the efficiency level of e-government have been proposed. E-government formation has altered the structure of public administration, while the knowledge economy has caused advanced technologies to develop rapidly and become an integral part of government activity. E-government improves the efficiency of government structures and facilitates the formation of a new democracy model. The complete openness of governmental activities to society andthe opportunity for citizens to directly participate in proposing solutions to governmental and local issues via online voting constitute the basis of edemocracy.

This article presented researchers' views on the transformation of public administration and the formation of electronic democracy. The transition process from representative democracy to direct democracy was analysed and meritocracy was considered as one of the mechanisms of public administration. According to the meritocrat, public administration must be trusted to persons with corresponding intellect and skills, who deserve to occupy the highest level of the social hierarchy. Although different approaches exist within the ideology of meritocracy, the transition to an information society and the rapid development of innovation technologies mean that meritocracy remains a mechanism for managing society.

Despite the different approaches to e-government and e-democracy in the literature, it can be concluded that e-government is established by the higher level of the hierarchy to serve the government interests. In contrast, e-democracy reflects the interests of citizens' and emerges from the lower level of the hierarchy. Hence, the realisation of the concept of e-government is directed toward the development of e-government, and establishing effective mechanisms of edemocracy will alter the views how to manage society.

\section{Acknowledgment}

This work was supported by the Science Development Foundation under the President of the Republic of Azerbaijan - Grant № EIF/GAM-2-2013-2(8)-25/03/1.

\section{References}

1. McLuhan M. Understanding Media: The Extensions of Man. Routledge and Kegan Paul, London, 1964, 318 p. 
2. Wahid F. The Current State of Research on eGovernment in Developing Countries: A Literature Review, In H. Scholl, M. Janssen, M. Wimmer, C. Moe \& L. Flak (Eds.), Electronic Government, Springer, 2012, vol. 7443, pp. 1-12.

3. Zhang H., Xu X., Xiao J. Diffusion of e-government: A literature review and directions for future directions // Government Information Quarterly, 2014, vol. 31, no.4, pp. 63-636

4. Fang I. A History of Mass Communication Six Information Revolutions, Focal Press, 1997, $320 \mathrm{p}$.

5. Robertson D.S. The Information Revolution // Communication Research, 1990, vol. 17, no.2, pp. 235-254

6. Drucker P.F. Management Challenges for the 21st Century, Elsevier, ButterworthHeinemann Ltd., Classic Collection, 1999, 224 p.

7. Rahman Sh., Rashid N., Yadlapalli A., Yiqun L. Determining factors of e-government implementation: a multi-criteria decision-making approach / Proceedings of PACIS 2014 Chengdu, China, 24-28 June, 2014, pp. 73-85.

8. Chen Y. C., Knepper R.Digital Government Development Strategies. Lessons for Policy Makers from a Comparative Perspective, In Electronic Government Strategies and Implementation. Idea Group publishing, 2005, 464 p.

9. Ozkan S., Kanat E.I. e-Government adoption model based on theory of planned behavior: Empirical validation // Government Information Quarterly, 2011, vol. 28, no. 4, pp. 503-513

10. Shareef M.A., Kumar V., Kumar U., Dwivedi Y.K. e-Government Adoption Model (GAM): Differing service maturity levels // Government Information Quarterly, 2011, vol. 28 , no. 1 , pp. 17-35

11. Bwalya K.J., Plessis T. Du and Rensleigh C. E-government implementation in Zambia prospects // Transforming Government: People, Process and Policy, 2014, vol. 8, no.1, pp. 101-130

12. Alshehri M., Drew S. E-government principles: implementation, advantages and challenges // Intnational Journal Electronic Business, 2011, vol. 9, no. 3, pp. 255-270

13. Siskos E., Askounis D., Psarras J. Multicriteria decision support for global e-government evaluation // Omega, 2014, vol.46, pp. 51-63.

14. SchedlerK., Scharf M.C. Exploring The Interrelations Between Electronic Government And the New Public Management - A Managerial Framework For Electronic Government / Workshop on Developing a Basic Research Program for Digital Government at the Kennedy School of Government at Harvard University, 2002, pp. 1-14.

15. Schedler K., Schmidt B. Managing the e-government organization // International Public Management Review, 2004, pp. 1-20.

16. Wimmer M.Knowledge Management in Electronic Government. Springer-Verlag, 2003

17. Meier A. eDemocracy \& eGovernment, Springer-Verlag. Berlin, Heidelberg, 2012, 226 p.

18. Williams R.W. Democracy, Cyberspace, and the Body, 2006,http://clogic.eserver.org/2006/williams.html

19. Carrizales T.Critical Factors in an Electronic Democracy: a Study of Municipal Managers // The Electronic Journal of e-Government,2008, vol. 6, no.1, pp. 23-30

20. Anttiroiko A.-V. Building Strong E-Democracy - The Role of Technology in Developing Democracy for the Information Age // Communications of the ACM, 2003, vol. 46, no. 9, pp. 121-128

21. Becker T. Teledemocracy: Bringing Power Back to the People // The Futurist, 1981,pp.6-9

22. Becker T. Teledemocracy, Section: E-Democracy, Category: Introduction to E-Democracy // Information Resources Management Association, 2007, pp. 1519-1520, www.irmainternational.org/viewtitle/11706/

23. Grossman L.K.The Electronic Republic. Reshaping Democracy in the Information Age. N.Y.: Viking (20 $0^{\text {th }}$ Century Fund), 1995, 290 p. 
24. FountainJ.Building the Virtual State. Information Technology and Institutional Change. Washington: Brooking Institution Press., 2001, 256 p.

25. Habermas J. The Structural Transformation of the Public Sphere: An Inquiry Into a Category of Bourgeois Society, MIT Press, 1991, $301 \mathrm{p}$.

26. Rheingold H.The virtual community: Homesteading on the electronicfrontier. Reading, Massachusetts: Addison-Wesley, 1993, 447 p.

27. Kaczmarczyk A. Cyberdemocracy as a Future Product of Political Systems Engineering // Frontiers in Science, 2011, vol. 1, no. 1, pp. 5-15.

28. Bimber B. The Internet and Political Transformation: Populism, Community, and Accelerated Pluralism // Polity, 1998, vol. 31, no 1, pp. 133-160.

29. Hill K.A., Hughes J.E.Cyberpolitics: Citizen Activism in the Age of the Internet, Rowman and Littlefield Publishers Inc., Oxford, 1998, 224 p.

30. Hilbert M. The Maturing Concept of E-Democracy: From E-Voting and Online Consultations to Democratic Value Out of Jumbled Online Chatter // Journal of Information Technology \& Politics, 2009, vol. 6, pp. 87-110.

31. Young M. The rise of the meritocracy, 1870-2033: An essay on education and inequality, Thames \& Hudson, London, 1958, 160 p.

32. Bell D. The Coming of Post-Industrial Society, New York, Basic Books, 1973, 259 p.

33. Bell D. On meritocracy and equality, National Affairs. Public Interest, 1972, vol. 29, pp. 29-68.

34. Daniels N. Merit and meritocracy, Philosophy \& Public Affairs, 1978, vol. 7, no. 3, pp. 206-223.

35. The National Strategy on development of information society in the Republic of Azerbaijan for 2014-2020 years, April 4 ${ }^{\text {th }}, 2014$, http://president.az/articles/11312 